\title{
SPOONS WITH APOSTLE FIGURES IN LITHUANIA
}

\author{
SKAISTE் ARDAVIČIŪTE்-RAMANAUSKIENE்
}

\begin{abstract}
Ten apostle spoons have been found in Lithuania during archaeological excavations and site surveys, and two have been brought to the museum by people who found them on their land. This article discusses their identification, material, context and provenance. Additionally, it is argued that apostle spoons, which for a long time were thought to be only used as christening gifts, had other purposes. The distribution map reveals that all the apostle spoons were found inland, with the largest number concentrated in Vilnius, the capital of the Grand Duchy of Lithuania. The apostle spoons that were found in Lithuania were probably made in the 17th century, and used until the first half of the 18th century. The features of the figures indicate that they were made in and imported from England and continental Europe. Of the 12 spoons analysed, only five apostles could be identified with certainty, and they correspond well with the most popular saints and names in the Grand Duchy of Lithuania in the 16 th and 17 th centuries.
\end{abstract}

Key words: apostle spoon, Lithuania, christening present, Post-Medieval, England, German-speaking regions.

DOI: http://dx.doi.org/10.15181/ab.v25i0.1837

\section{Introduction}

The saints played an important role in Late Medieval and Early Post-Medieval daily life. The desire for patronage and protection from saints in people's daily life is reflected in the religious images and inscriptions on tableware and other utilitarian objects (Sundmark 2017). An apostle spoon is a spoon with the figure of one of the Twelve Apostles, or very rarely another saint, at the termination of the spoon's handle or bowl, with distinct attributes. Apostle spoons were made in sets or individually. Sets of 12 or 13 spoons were made from silver, sometimes partially gilded, and usually consisted of the Twelve Apostles and either Jesus Christ or the Virgin Mary. The last is called a 'master spoon'. Individual spoons were made from silver or pewter, but mostly from brass. Apostle spoons were produced mainly in Western Europe in the Late Medieval and Post-Medieval periods, with silver examples known from the second half of the 15 th century, and base metal examples, particularly from brass, from the second half of the 16 th to the late 17 th century. They were popular on the Continent, notably in Germany and the Netherlands, but they were never in vogue there as much as in England (Price 1908; Emery 1976; Homer 1999; Immonen 2005).

Apostle spoons are a rare find during excavations, and the research on them is very limited, dispersed, and in many cases focused on collectors and antiquarians, making it difficult to construct a general picture of the phenomenon of the apostle spoon in Late Medieval and
Post-Medieval Europe. The lack of systematic in-depth studies on apostle spoons has led to many unanswered questions, making it difficult primarily to provenance them. As V. Immonen noted, 'all the arguments about apostle spoons are currently based on anecdotes and unarticulated observations rather than any statistical or contextual treatment of the material' (Immonen 2005, 194). While silver apostle spoons have received more attention because of their material, pewter and brass spoons have not been systematically studied.

The aim of this research is to analyse apostle spoons, a previously unstudied artefact type in Lithuania, and to discuss aspects of their identification, material, context and provenance. In addition, it is argued that apostle spoons were not made just to be presented as christening gifts, as most studies would lead us to believe. This paper expands the current understanding of apostle spoons, and will act as a reference for future research.

Current research on apostle spoons is practically nonexistent, and based on old studies that were intended mainly for collectors. C.G. Rupert's (1929) book Apostle Spoons, their evolution from earlier types and the Emblems used by the Silversmiths for the Apostles is the only work devoted exclusively to the study of silver apostle spoons. His research focused on sets of silver apostle spoons from England, and the iconography of apostle figures, leaving many questions unanswered and old hypotheses unchallenged. Other authors have mentioned apostle spoons only as a minor part of larger studies on spoons, or cutlery in general, without providing an in-depth analysis, but giving a valuable

\section{II}

THE MATERIAL OF MEDIEVAL AND NEW AGES: SOCIAL INTERACTIONS BETWEEN COMMUNITIES 
insight for future studies (Jackson 1892; Price 1908; Emery 1976; Marquardt 1997; Homer 1999). For example, F.G.H. Price (1908) was the first to give a short description of brass apostle spoons, and illustrated the maker's marks found on this type of spoon. J. Emery (1976) noticed a difference between silver apostle spoons made in Germany, the Netherlands and England based on their apostle figures, and was the first to argue the insular origin of brass apostle spoons. K. Marquardt (1997) devoted a paragraph in his book to the study of Swiss silver apostle spoons, and noted that some apostles were more popular than others. A completely new approach to the study of apostle spoons was introduced by V. Immonen's (2005) article on six apostle spoons from Finland. This was the first study to analyse copper alloy apostle spoons from northern Europe, their probable production centres, distribution patterns, and problems in studying them.

\section{Apostle spoons as christening presents: between truth and myth}

It is widely believed that apostle spoons were made only as christening gifts. This association might have come from 19th-century English literature, where authors, without plausible sources, began constructing the story of apostle spoons as customary christening presents. For example, G. Colman (1811), in analysing the dramatic works of Beaumont and Fletcher, identifies all the spoons that were given as christening presents as apostle spoons. Furthermore, he even identifies the number of silver apostle spoons which were given by godparents of different social classes: from the wealthy 12 , less wealthy four and one spoon from the poor (Colman 1811, 195). H.O. Westman (1844) took this description even further, identifying four spoons as the Four Evangelists, and one spoon 'with the effigies of the saint after whom the infant was named, or under whose protection it had been placed by its parents'. Later, this association carries on in various works without being questioned, and even takes on new interpretations. For example, M. Howard (1903) argues that the number of spoons in a set represents the number of sponsors, and not the social status of the sponsors. Seeing apostle spoons without question as christening presents has continued until today (Harris 1950; Wilson 1984; Carver 1997; Homer 1999; Kriegseisen 2014).

However, the unquestioning association of apostle spoons with christening presents was noticed by J. Jackson, who argues that the purpose of this type of spoon should not be restricted only to this custom (Jackson 1892, 135). Unfortunately, he does not give further explanation why. V. Immonen (2005) raised the question whether apostle spoons were made only as christening presents, and wondered if this assumption was created by English written sources. However, he too did not follow it up. And while it is true that some silver apostle spoons bear inscriptions of children's names and their date of birth, the same inscriptions were also made on other types of silver spoons (Homer 1999, 4). Interestingly, apostle spoons from base metals have no such inscriptions at all.

A 1512 inventory of the Guild and Fraternity of St John the Baptist in the City of London (also known as the Merchant Taylors Company of London) lists, among other types of spoons, ' 6 spones with Saint John Baptist on the spones endes [...] a gilt spone with Saint John on the knoppe, and the stele graven with his name [....] spones, whyte, with Saint John upon the knoppes, 12 dosen and one spone' (Jackson 1892, 123). St John the Baptist was the patron saint of the company, and although the purpose of these spoons is unclear, it could be surmised that at least one purpose included representation and diplomatic gift giving.

An interesting entry is found in an inventory of silver tableware of the city council of Gdansk. In a 1634 entry, a separate tab for silver tableware sets used for travel and for the representation of the city is mentioned (Kriegseisen 2014, 1). Among other silver tableware with the city's coat of arms were 12 partly gilded silver apostle spoons. While they might have been given as diplomatic gifts if the need arose, it is highly unlikely that silver spoons used for travel and representing a city would be given away as christening gifts.

Therefore, there is no evidence to say with certainty that apostle spoons were given only just as christening gifts, as works of English literature suggest. As we can see from the inventory of silver tableware of the city council of Gdansk, they were also used for the representation of the city, or, as the Merchant Taylors Company of London inventory showed, to represent their patron saint.

\section{Apostle spoons in Lithuania}

Surviving 16th and 17th-century written records from the Grand Duchy of Lithuania are quite scarce, and unfortunately hardly any refer to the kinds of spoons that people owned. However, spoons with apostle figures are mentioned in one inventory. In 1684, among other types of spoon, the Vilnius merchant's wife Anastasia Gilewicz had 'siedm łyżek plaskich pod apostołami': seven silver spoons with apostles (Frick 2008, 201). The expression 'plaskich pod' might mean that the spoons had apostle figures not at the end of their handle but where the handle meets the bowl. Alternatively, it 


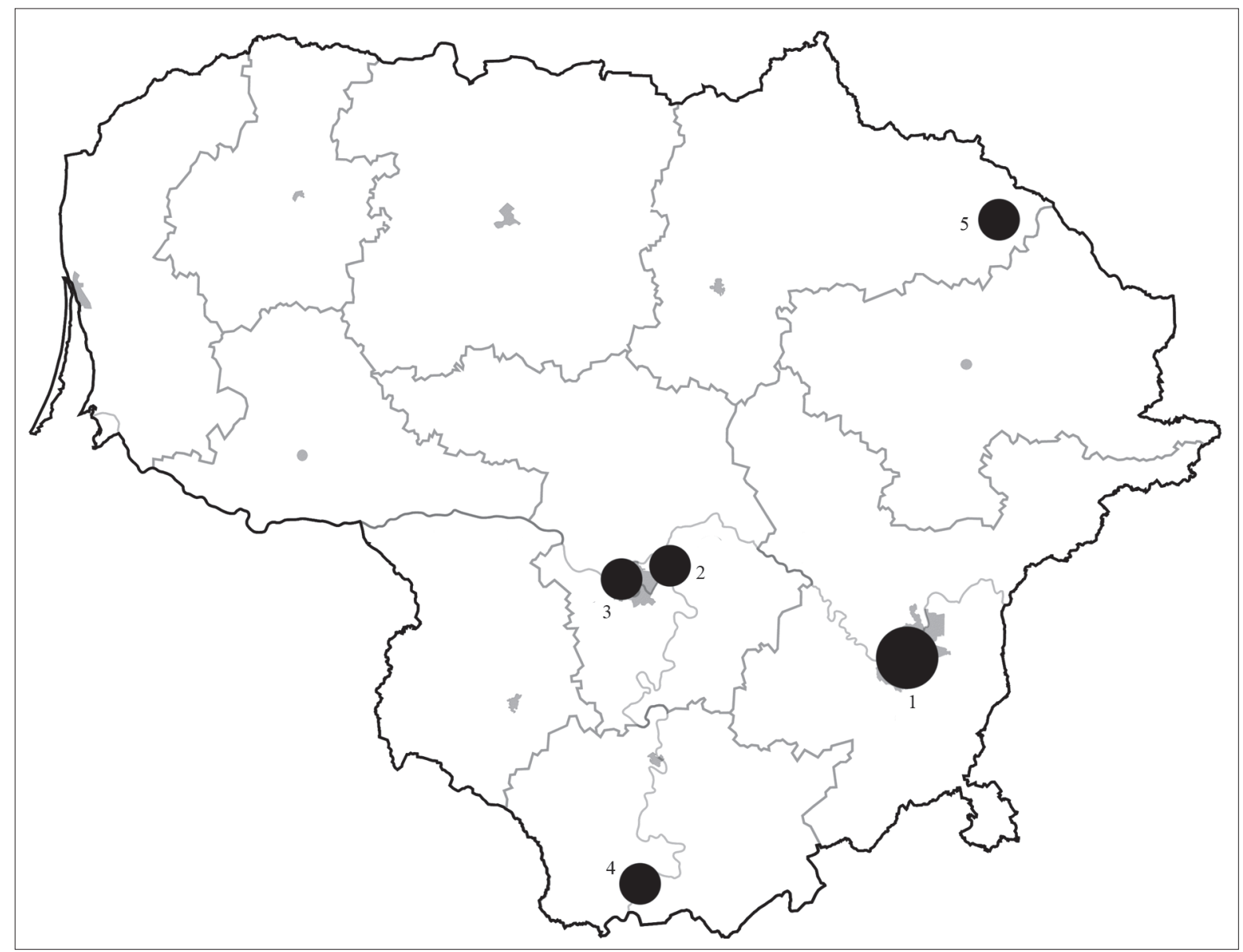

Fig. 1. Find-locations of spoons with apostle figures: 1 Vilnius; 2 Jakštonys; 3 Kaunas; 4 Leipalingis; 5 Skèmai.

could simply have meant that the bowls of the spoons were shallow. Similar mentions of apostle spoons can be found in the inventories of citizens of Poland, all of them made from precious metals and belonging to wealthy citizens (Dolczewski 2006, 63).

Ten apostle spoons have been found in various locations in Lithuania in archaeological excavations and site surveys (Table 1). The distribution map shows that all of them were found inland, with the largest number concentrated in Vilnius, the capital of the Grand Duchy of Lithuania (Fig. 1). Two were brought to the museum by people who found them on their land.

In order to identify what alloys were used to make these apostle spoons, nine were qualitatively and quantitatively analysed. An analysis of four apostle spoons from the National Museum-Palace of the Grand Dukes of Lithuania was carried out using scanning electron microscopy with energy dispersive X-ray spectrometry (SEM-EDX). Microchemical and X-ray fluorescence (XRF) analyses were carried out on five apostle spoons from the National Museum of Lithuania. Of the nine analysed fragments of spoons, only the one from
Šventaragis Street had a different composition from the rest, and was made of lead and tin alloy. The eight other spoons were made from copper and zinc alloy, with minor traces of tin, lead and iron. LDKVR inv. 1470 is the only one that did not show any traces of tin, lead or iron, and was made from pure copper and zinc alloy. LNM inv. AM 73:1 is comprised of nearly $92 \%$ copper, $4 \%$ zinc, and traces of iron, lead and tin, and therefore should be considered to be made from copper rather than brass. LDKVR inv. 31 has traces of silvercoloured coating on the handle, which was identified as tin, showing that this apostle spoon, or at least its handle, was tin-plated. Tin-plating was also identified on two other spoons (LNM inv. AM 3:18, AV 75:1). The analysed spoons consist approximately $75 \%$ to $85 \%$ of copper in the alloy, and these ratios in the copper-zinc alloy match with the previously analysed three 17 thcentury brass spoons from England (Price 1908; Homer 1999; Dungworth 2005). However, this composition is typical of all other cast or wrought Post-Medieval brass objects in Europe (Dungworth 2005, 232-233).

\section{II}

THE MATERIAL OF MEDIEVAL AND NEW AGES: SOCIAL INTERACTIONS BETWEEN COMMUNITIES 
Table 1. Spoons with apostle figures.

\begin{tabular}{|c|c|c|c|c|c|c|c|c|c|}
\hline $\begin{array}{l}\text { Fig. } \\
\text { No. }\end{array}$ & Inv. No. & Apostle & $\begin{array}{l}\text { Dimen- } \\
\text { sions } \\
(\mathrm{cm})\end{array}$ & $\begin{array}{l}\text { Figure's } \\
\text { dimensions } \\
\text { with a base } \\
(\mathbf{c m}) \\
\end{array}$ & Base type & $\begin{array}{l}\text { Stem } \\
\text { type }\end{array}$ & Material & Dating & Provenance \\
\hline 2 & $\begin{array}{l}\text { LDKVR } \\
1470\end{array}$ & St Andrew & $4.2 \times 1.2$ & $3.4 \times 1.2 \times 0.6$ & $\begin{array}{l}\text { oval with } \\
\text { oblique } \\
\text { grooves }\end{array}$ & oval & brass & $\begin{array}{l}17 \text { th-18th } \\
\text { century }\end{array}$ & $\begin{array}{l}\text { England or } \\
\text { German-speak- } \\
\text { ing regions }\end{array}$ \\
\hline 3 & \begin{tabular}{|l} 
LDKVR \\
1474
\end{tabular} & $\begin{array}{l}\text { St Bartho- } \\
\text { lomew? }\end{array}$ & $14.8 \times 4.5$ & $3.3 \times 0.9 \times 0.6$ & $\begin{array}{l}\text { double } \\
\text { diamond }\end{array}$ & diamond & brass & $\begin{array}{l}17 \text { th-18th } \\
\text { century }\end{array}$ & $\begin{array}{l}\text { German-speak- } \\
\text { ing regions }\end{array}$ \\
\hline 4 & $\begin{array}{l}\text { LDKVR } \\
2221\end{array}$ & $?$ & $4.3 \times 1.1$ & $3.1 \times 1.1 \times 0.6$ & $\begin{array}{l}\text { hexagonal } \\
\text { with a col- } \\
\text { lar }\end{array}$ & oval & brass & $\begin{array}{l}17 \text { th-18th } \\
\text { century }\end{array}$ & $\begin{array}{l}\text { England or } \\
\text { German-speak- } \\
\text { ing regions }\end{array}$ \\
\hline 5 & $\begin{array}{l}\text { LDKVR } \\
31\end{array}$ & $\begin{array}{l}\text { St Mat- } \\
\text { thew? }\end{array}$ & $4.7 \times 1.5$ & $3.5 \times 1.5 \times 0.7$ & hexagonal & $\begin{array}{l}\text { hexago- } \\
\text { nal with } \\
\text { a groove }\end{array}$ & brass, tin & $\begin{array}{l}17 \text { th-18th } \\
\text { century }\end{array}$ & England \\
\hline 6 & $\begin{array}{l}\text { LNM AV } \\
76: 1\end{array}$ & $?$ & $4, .7 \times 1.9$ & $3.3 \times 1.6 \times 0.6$ & & $\begin{array}{l}\text { hexago- } \\
\text { nal }\end{array}$ & $\begin{array}{l}\text { lead and tin } \\
\text { alloy }\end{array}$ & 17 th century & Poland \\
\hline 7 & $\begin{array}{l}\text { LNM AV } \\
75: 1\end{array}$ & $?$ & $5.6 \times 0.9$ & $3.3 \times 0.9 \times 0.7$ & $\begin{array}{l}\text { double rec- } \\
\text { tangular }\end{array}$ & $\begin{array}{l}\text { hexago- } \\
\text { nal with } \\
\text { a groove }\end{array}$ & brass, tin & $\begin{array}{l}17 \text { th-18th } \\
\text { century }\end{array}$ & $\begin{array}{l}\text { German-speak- } \\
\text { ing regions }\end{array}$ \\
\hline 8 & $\begin{array}{l}\text { LNM AM } \\
3: 18\end{array}$ & $\begin{array}{l}\text { St Bartho- } \\
\text { lomew? }\end{array}$ & $11.1 \times 1.3$ & $3.1 \times 1.2 \times 0.6$ & $\begin{array}{l}\text { double } \\
\text { hexagonal }\end{array}$ & $\begin{array}{l}\text { hexago- } \\
\text { nal }\end{array}$ & brass, tin & 17 th century & England \\
\hline 9 & $\begin{array}{l}\text { LNM AM } \\
57: 6\end{array}$ & $?$ & $4.2 \times 1.5$ & $3.4 \times 1.5 \times 0.6$ & hexagonal & $\begin{array}{l}\text { hexago- } \\
\text { nal with } \\
\text { a groove }\end{array}$ & brass & 17 th century & England \\
\hline 10 & $\begin{array}{l}\text { LNM AM } \\
71: 1\end{array}$ & $\begin{array}{l}\text { St James } \\
\text { the Greater }\end{array}$ & $6.4 \times 1.2$ & $2.7 \times 1.2 \times 0.6$ & oval & $\begin{array}{l}\text { hexago- } \\
\text { nal }\end{array}$ & copper & 17 th century & $\begin{array}{l}\text { England or } \\
\text { German-speak- } \\
\text { ing regions }\end{array}$ \\
\hline 11 & $\begin{array}{l}\text { KMM } \\
\text { GEK } \\
11085 \\
\end{array}$ & St Matthew & $11.9 \times 1.5$ & $3.5 \times 1.5 \times 0.7$ & hexagonal & $\begin{array}{l}\text { hexago- } \\
\text { nal with } \\
\text { a groove }\end{array}$ & $\begin{array}{l}\text { copper alloy, } \\
\text { tin }\end{array}$ & $\begin{array}{l}17 \text { th-18th } \\
\text { century }\end{array}$ & England \\
\hline 12 & AIM PŠ 45 & St Andrew & $8.9 \times 1$ & $3 \times 1 \times 0.6$ & $\begin{array}{l}\text { oval with } \\
\text { oblique } \\
\text { grooves }\end{array}$ & $\begin{array}{l}\text { oval } \\
\text { with a } \\
\text { groove }\end{array}$ & copper alloy & 17 th century & $\begin{array}{l}\text { England or } \\
\text { German-speak- } \\
\text { ing regions }\end{array}$ \\
\hline 13 & \begin{tabular}{|l} 
AIM PŠ \\
112
\end{tabular} & $\begin{array}{l}\text { St James } \\
\text { the Greater }\end{array}$ & $4.7 \times 1.5$ & $3.5 \times 1.5 \times 0.7$ & hexagonal & $\begin{array}{l}\text { hexago- } \\
\text { nal }\end{array}$ & $\begin{array}{l}\text { copper alloy, } \\
\text { tin }\end{array}$ & 17 th century & England \\
\hline
\end{tabular}

Apostle spoons from Vilnius, the capital of the Grand Duchy of Lithuania

The Palace of the Grand Dukes of Lithuania. The largest number of apostle spoons, four in total, were found during large-scale archaeological excavations in the grounds of the Palace of the Grand Dukes of Lithuania in Vilnius in 2002, while excavating the entrance areas in the north, south, east and west buildings of the palace (Ožalas 2003; Rackevičius 2003). The first three (LDKVR inv. 1470, 1474 and 2221) were found in a disturbed cultural layer together with 17th and 18th-century finds and coins from the second half of the 17th and 18th centuries. The layer was disturbed at the end of the 18th century when laying water pipes (Rackevičius 2003). The same disturbed layer contained a fragment of a spoon with a 'strawberry' or 'pine cone' finial, and the bowl of a spoon with a barely visible maker's mark, three parallel spoons in a circle with the letters VBL, the remaining ones from the inscription DOVBLE WHITED. The first apostle spoon (LDKVR inv. 1470), or to be more precise, a fragment of it, comprises a figure and a short length of stem, which is oval in cross-section (Fig. 2). The rest of the handle and the bowl are missing. The figure is standing on an oval base decorated with oblique grooves, and is wearing a long robe and holding either a staff or a saltire cross in its hands. Although the figure is too worn to discern the exact attribute in the hands, judging from the barely visible $X$ shape, it could be a saltire cross, an attribute of St Andrew. A similar apostle spoon, but holding a different attribute, was found in Turaida Castle in Latvia (Graudonis 2003, f. 57:3). 


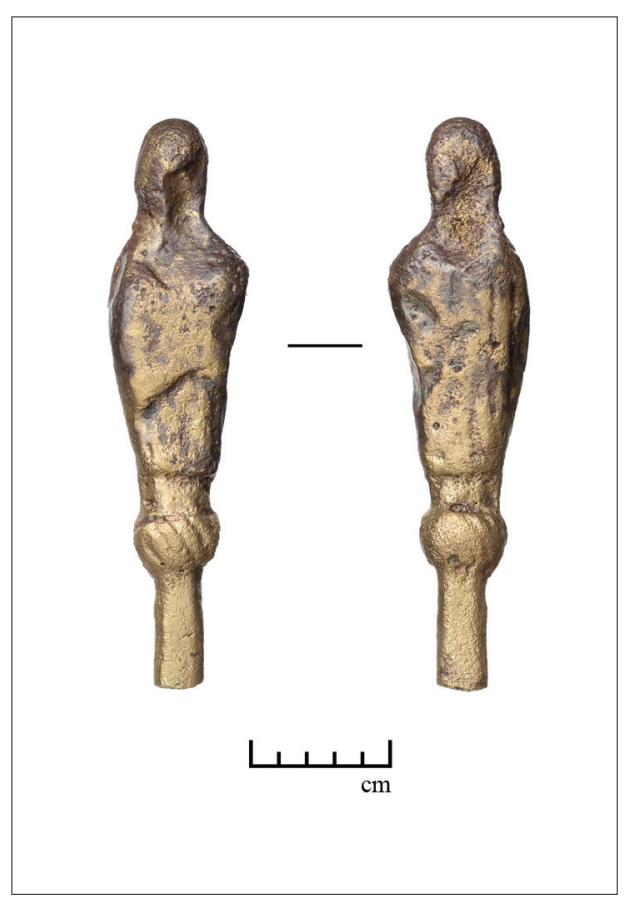

Fig. 2. An apostle spoon from the Palace of the Grand Dukes of Lithuania (LDKVR inv. 1470). Front and back (photograph by V. Abramauskas (C) National MuseumPalace of the Grand Dukes of Lithuania).

The second brass apostle spoon (LDKVR inv. 1474), with a diamond sectioned handle and upper half of the bowl, has a well-proportioned and statue-like figure, standing on a diamond-shaped double base, dressed in a loose flowing robe (Fig. 3). The figure is holding a short object in both its hands, which could be a flaying knife, an attribute of St Bartholomew. A similar apostle spoon with St Bartholomew is illustrated in J. Amme's catalogue (Amme 2007, ff.51). The third fragment of a brass apostle spoon (LDKVR inv. 2221) comprises a very worn figure and a short length of handle, oval in cross-section (Fig. 4). The figure is standing on what seems to have been a hexagonal base with a collar beneath it. It is holding a book in its left hand, and a long tapering object in its right hand. It could be a sword ( $\mathrm{St}$ Paul), a staff (St James the Greater or Lesser), or even a saw (St Simon Zealot). However, the figure is too worn to discern exactly what the item is in its hands, making it hard to identify the apostle depicted. The fourth fragment of brass apostle spoon (LDKVR inv. 31) was found in a mixed deposit together with 17th and 19th-century coins and 17th-century ceramics (Ožalas 2003) (Fig. 5). It comprises a figure and a short length of hexagonal handle with a groove in the middle. The figure is standing on a hexagonal base, is wearing a long robe, and holding a book in its left hand. It is not exactly clear what the figure is holding or used to hold in the right hand. At first glance, it seems to be a money bag with a cross incised on it, an attribute of St Mat-
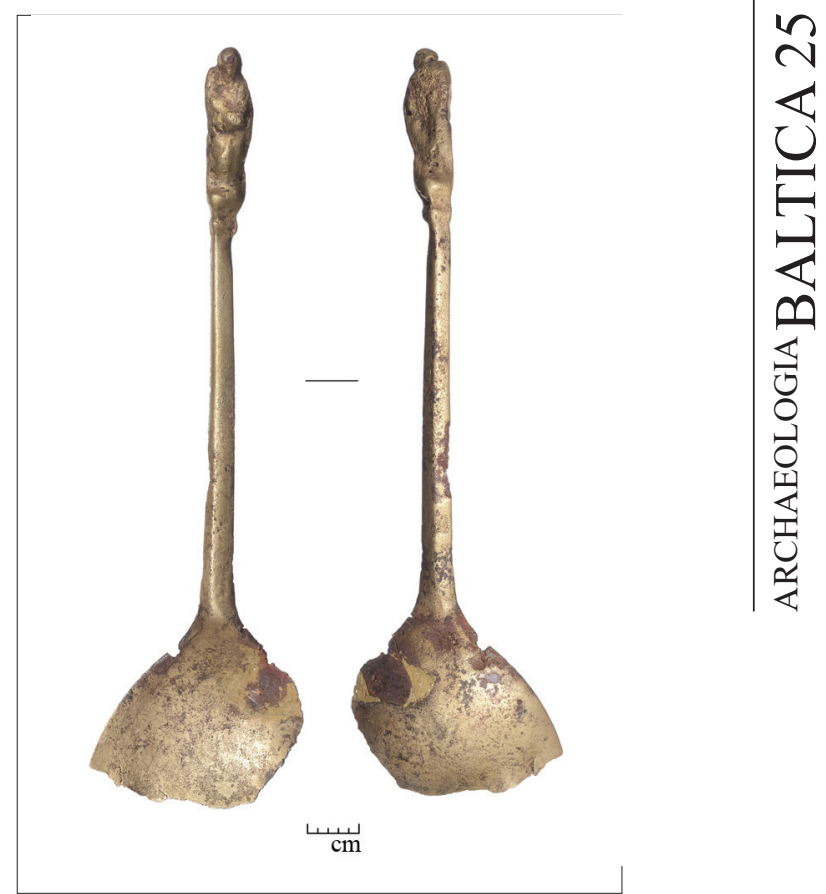

Fig. 3. An apostle spoon from the Palace of the Grand Dukes of Lithuania (LDKVR inv. 1474). Front and back (photograph by V. Abramauskas (C) National MuseumPalace of the Grand Dukes of Lithuania).

thew. However, on closer examination, it seems that the small vertical groove could have been made to hold a separately cast object, such as a staff, a spear, a saw, or anything else long and shafted.

All four apostle spoons were found in service courtyards of the palace, and therefore might have belonged to servants who discarded them as broken items. Or they might have belonged to Vilnius townspeople or petty nobles who started living in the ruins of the palace after its destruction in 1655 .

Šventaragis Street. A fragment of a lead and tin alloy apostle spoon (LNM inv. AV 76:1) was found during archaeological excavations in Šventaragis Street in 2013 (Fig. 6). It was found in the filling of a ditch outside the wall of the Palace of the Grand Dukes, together with a 16th-century cloth seal from England, coins from the second half of the 17th century, and 16th and 17th-century ceramics (Veževičienè 2014). This fragment of apostle spoon is different from the previous ones, because the figure was located not at the end of the handle but connected at its widest part to the bowl. The end of the handle would originally have been decorated with a crown, baluster, mascaron, or some other type of finial (Marekowska 1954). The fragment consists of a two-sided plate and a short length of a hexagonal handle. The upper part of the handle and bowl are missing. An apostle is depicted on one side, holding a book in his left hand and an un-

\section{II}

THE MATERIAL OF MEDIEVAL AND NEW AGES: SOCIAL INTERACTIONS BETWEEN COMMUNITIES 


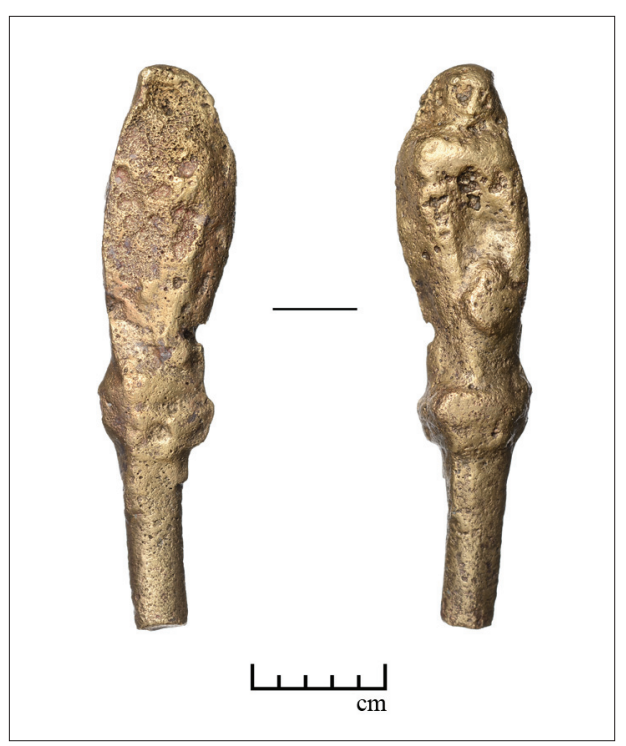

Fig. 4. An apostle spoon from the Palace of the Grand Dukes of Lithuania (LDKVR inv. 2221). Front and back (photograph by V. Abramauskas (C) National MuseumPalace of the Grand Dukes of Lithuania).

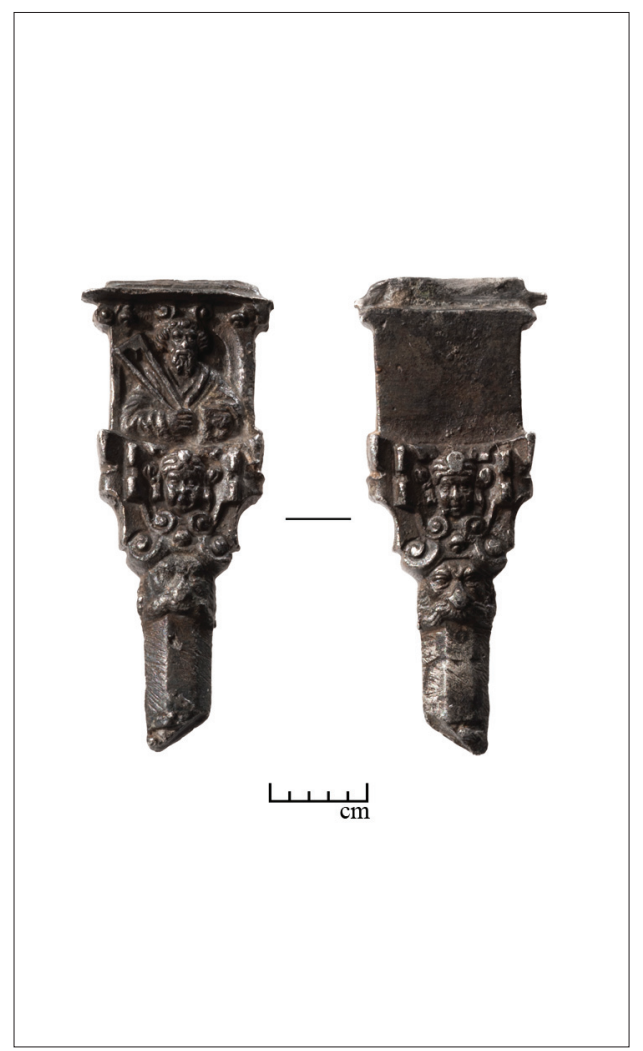

Fig. 6. The apostle spoon from Šventaragis Street (LNM inv. AV 76:1). Front and back, rotated (photograph by K. Stoškus

(C) National Museum of Lithuania).

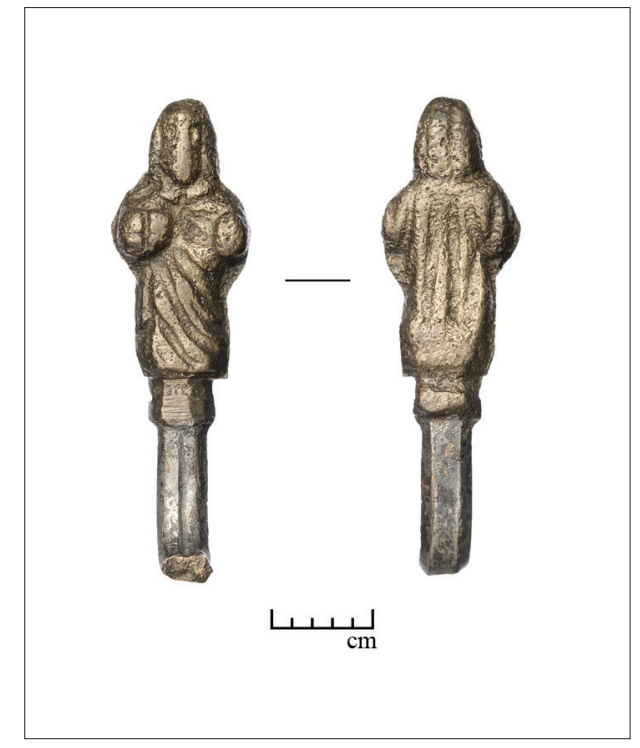

Fig. 5. An apostle spoon from the Palace of the Grand Dukes of Lithuania (LDKVR inv. 31). Front and back (photograph by V. Abramauskas (C) National MuseumPalace of the Grand Dukes of Lithuania).

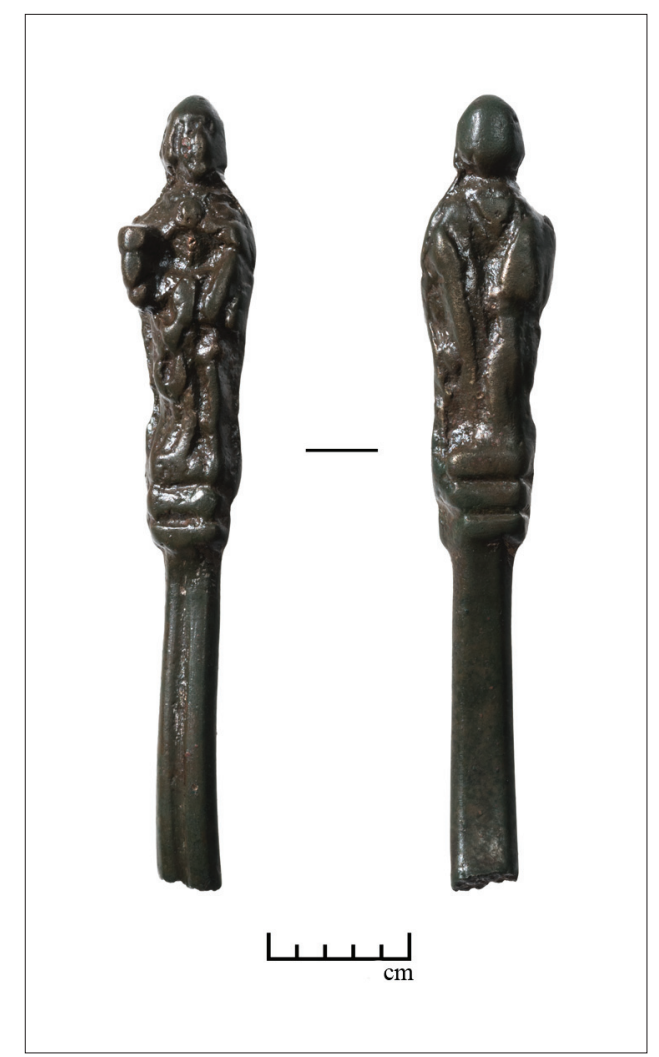

Fig. 7. The apostle spoon from Pylimo Street 56 (LNM inv. AV 75:1). Front and back (photograph by K. Stoškus

(C) National Museum of Lithuania). 
identified object or multiple objects in the right. Underneath the apostle is a woman's head, and below it is a mascaron, shown devouring the handle. The other side of the plate is blank, with the same motifs underneath it as on the side with the apostle. The blank side of the plate was meant for the coat of arms of the owner of the spoon to be engraved after purchasing the spoon, but if the spoon (or spoons) were ordered specifically, the coat of arms were cast on the other side together with the whole spoon (Marekowska 1954; Avižinis 2017, f. I.1). An identical depiction of the Šventaragis Street apostle is found on one of 12 apostle spoons with the Szeliga and Przeginia coats of arms in the National Museum in Kraków, Poland (Kilijańska 2018). The Šventaragis Street apostle spoon might have belonged to residents of the palace, to nobles from one of the nearby residences, or even to ordinary citizens. This type of apostle spoon was made only from silver, and although other spoons made from noble metals were copied, there are no known examples of this type in base metals. Furthermore, the material of the spoon is lead and tin alloy, which was not used for making spoons. However, this alloy has an attractive silver colour, so it is possible that the spoon was a forgery, and was passed off, or it was hoped to pass it off, as a silver one.

Pylimo Street 56. Another fragment of an apostle spoon (LNM inv. AV 75:1) was found in the filling of a ditch outside the 16th-century city wall of Vilnius during archaeological excavations at Pylimo Street 56 in 2017-2018 (Ostrauskienè 2018) (Fig. 7). The disturbed cultural layer in which the spoon was found contained mainly coins from the second half of the 17th century, and 16th and 17th-century ceramics (Ostrauskienè 2018). Citizens used to throw household waste into the ditches outside the city wall, until it was demolished in the 19th century, so the apostle spoon might have belonged to a citizen until it was discarded as broken. The fragment comprises of a figure and a short length of hexagonal handle with a groove in the middle. The well-proportioned figure is standing on a double rectangular base, and is wearing a long flowing robe under a cloak. The object in its right hand could be a scroll, a book, or even a cup. If it is a cup, the apostle could be St John. The figure is holding a small object in its left hand which looks like a tied rope (a secondary attribute of St Andrew). Alternatively, the small rope-like object could be the money bag of St Matthew.
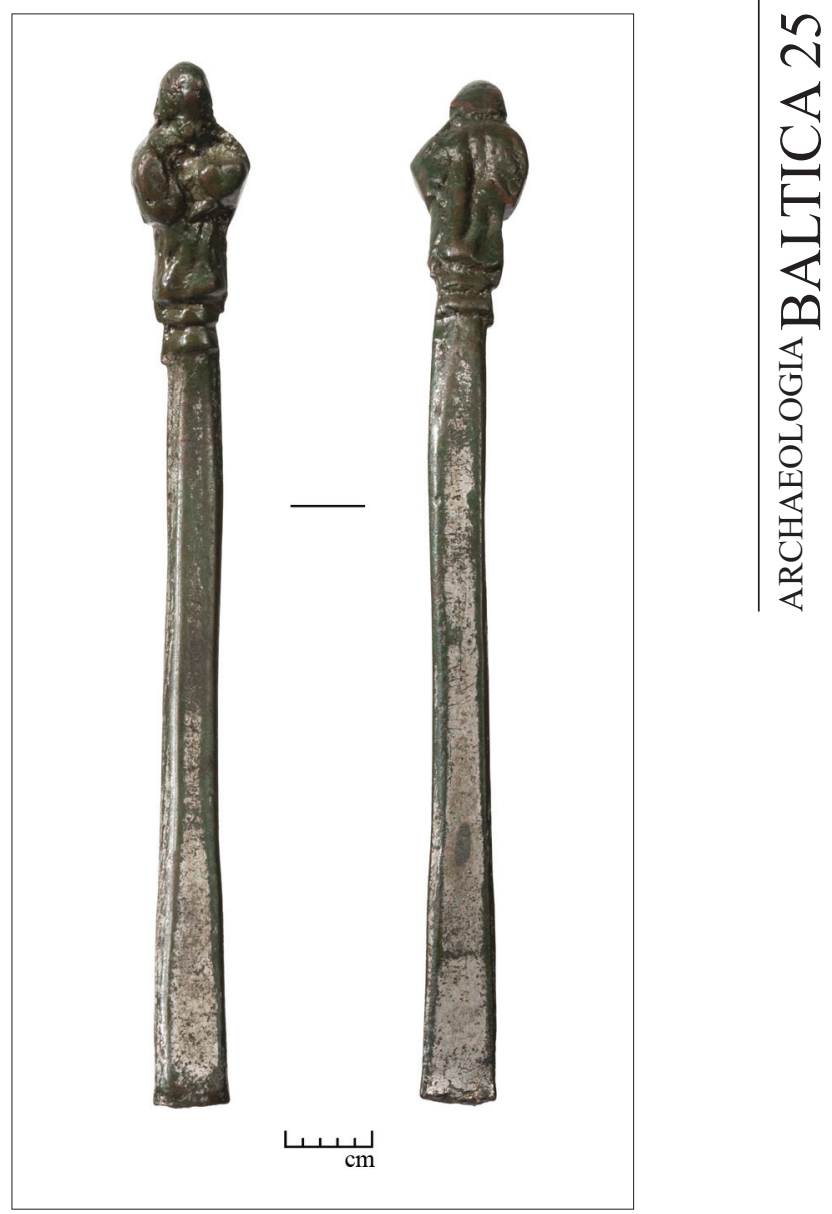

Fig. 8. The apostle spoon from Skemai manor (LNM inv. AM 3:18). Front and back (photograph by K. Stoškus

(C) National Museum of Lithuania).

\section{Apostle spoons from other parts of Lithuania}

Although brass is not a precious metal, spoons made from it were still valuable in the homes of the lesser nobility in the Grand Duchy of Lithuania. Surviving manor inventories of the lesser nobility from the 16th to the first half of the 17th century mention spoons made from brass and pewter (Dambrauskaite 2017, 116). And although they are not described in detail, making it impossible to know what types of spoons the lesser nobility had, the archaeological data shows that apostle spoons were among the items they had in their homes. Three apostle spoons were found in 16th to 18th-century manors in various parts of Lithuania, and
II

THE MATERIAL OF MEDIEVAL AND NEW AGES: SOCIAL INTERACTIONS BETWEEN COMMUNITIES 


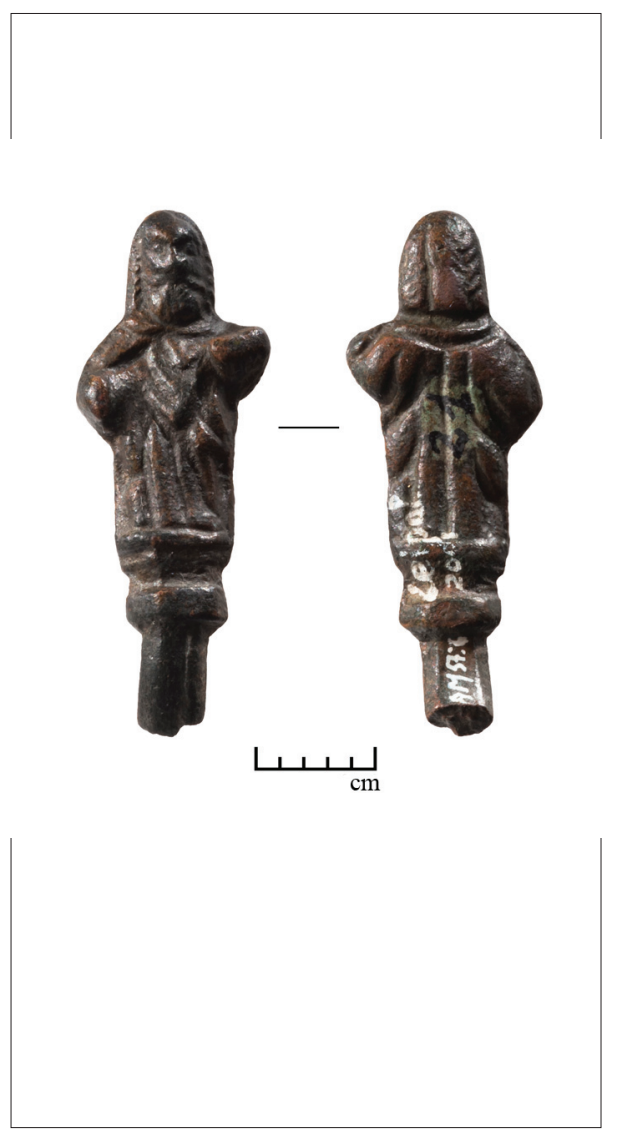

Fig. 9. The apostle spoon from Leipalingis manor (LNM inv. AM 57:6). Front and back (photograph by K. Stoškus (C) National Museum of Lithuania).

undoubtedly belonged to the owners. Unfortunately, the lack of historical data on these manors makes it hard to identify who exactly could have owned them.

Skèmai (Rokiškis district). During small-scale archaeological excavations at Skemai manor in 1994, a resident brought a fragment of a brass apostle spoon together with 17 th-century coins that he had found on the surface of the earth in the grounds of the manor (Ivanauskas 2003, 10). Excavations showed that the manor was probably built in the first half of the 17th century, and stood until the mid-18th century (Ivanauskas 2003,11$)$. In addition to 17 th-century tiles with a coat of arms, a copper alloy spoon with a strawberry or pine cone finial and a maker's mark (three parallel spoons) was also found. Judging by the 17th-century tiles with the coat of arms, the manor belonged to the lesser nobility. The fragment of brass apostle spoon (LNM inv. AM 3:18) consists of the figure and a slightly bent tapering trapezoid handle (Fig. 8). The figure is standing on a double hexagonal base, is wearing a long robe, and is holding a book in the left hand. It is not exactly clear what the figure is holding in the other hand, but the object is short and cannot be a staff, cross

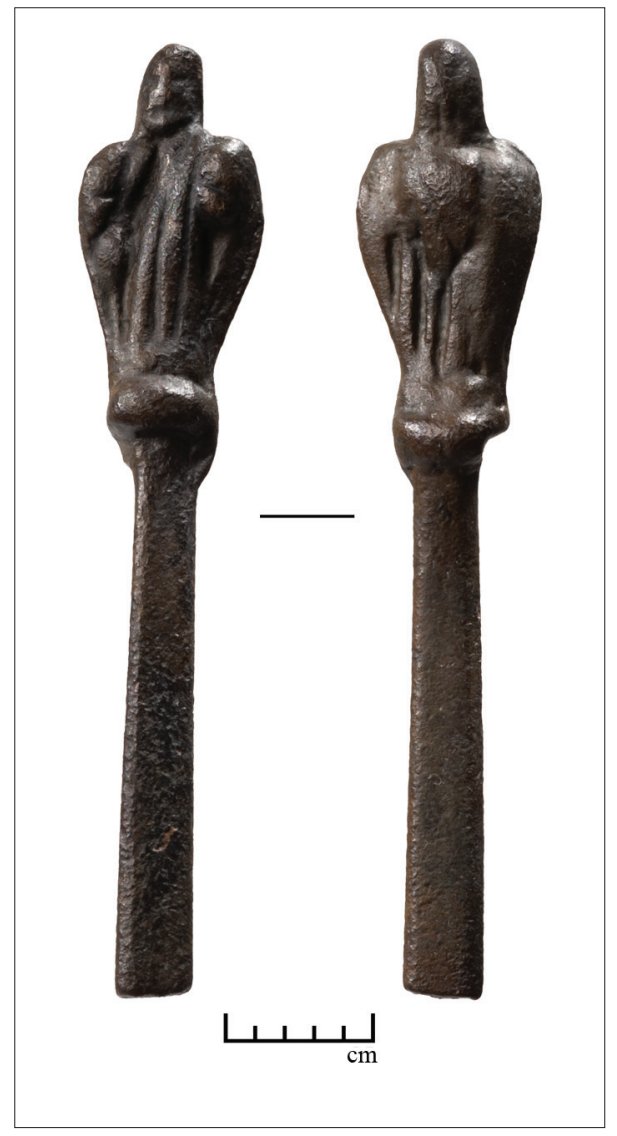

Fig. 10. The apostle spoon from Jakštonys manor (LNM inv. AM 71:1). Front and back (photograph by K. Stoškus

(C) National Museum of Lithuania).

or other long shafted object. It could be a flaying knife, an attribute of St Bartholomew, or a bag of money (an attribute of St Matthew), although if it is, it should be round and not oblong. Therefore, it is more likely that the apostle depicted is St Bartholomew.

Leipalingis (Druskininkai municipality). Another fragment of a brass apostle spoon (LNM inv. AM 57:6) was found in 2001 while surveying the site of Leipalingis manor with a metal detector (Ivanauskas 2001) (Fig. 9). A small-scale excavation nearby revealed ceramics and coins dating from the 17th century (Ivanauskas 2001). According to historical data, in the 16th and 17th centuries Leipalingis manor belonged to the Sapiega family of nobles (Miškinis 1999, 372). The fragment of brass apostle spoon comprises a figure and a short length of hexagonal handle with a groove in the middle. The handle is bent outwards slightly. The figure is standing on a hexagonal base, is wearing a long robe, and is holding an open book in the left hand. The object that used to be held in the right hand is lost, making it impossible to identify the apostle. 


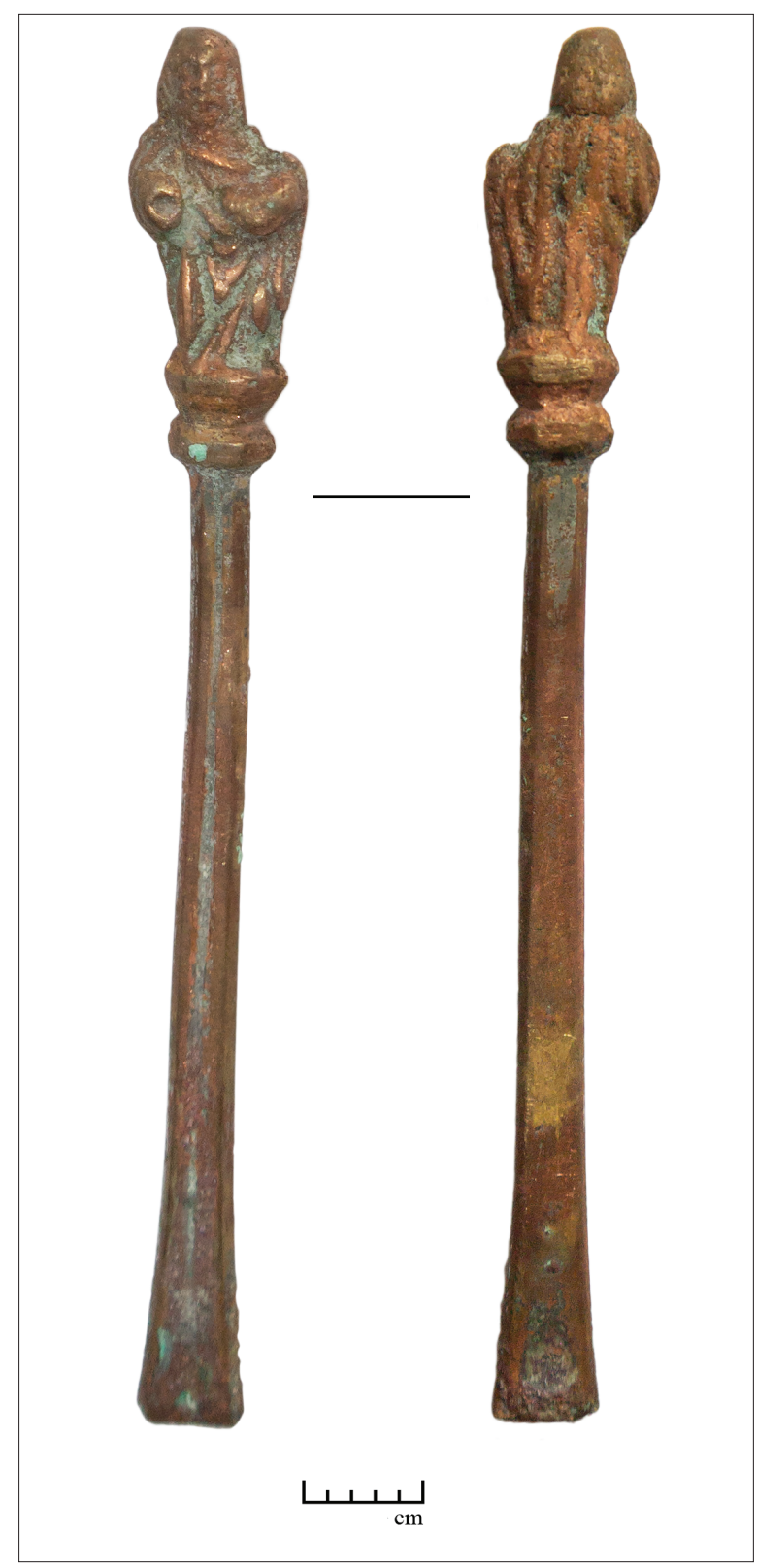

Fig. 11. The apostle spoon from Kaunas (KMM GEK 11085) (photograph by Skaistė ArdavičiūtèRamanauskienè).

Jakštonys (Kaunas district). A fragment of a brass apostle spoon (LNM inv. AM 71:1) was found together with coins from the second half of the 17th century at Jakštonys manor in 2002, while surveying the cultural layer that was washed away by the Kaunas Lagoon (Ivanauskas 2003) (Fig. 10). The fragment comprises a figure and a short length of oval handle. The figure is standing on an oval base, is wearing a long robe, and is holding an open book in the left hand. Although the object which used to be held in the right hand is lost, the hat on the figure's back indicates that the figure is St James the Greater. The main attributes of St James the Greater are a pilgrim's staff and a hat, and he is the only one who is usually depicted wearing a pilgrim's hat (Immonen 2005, 189).

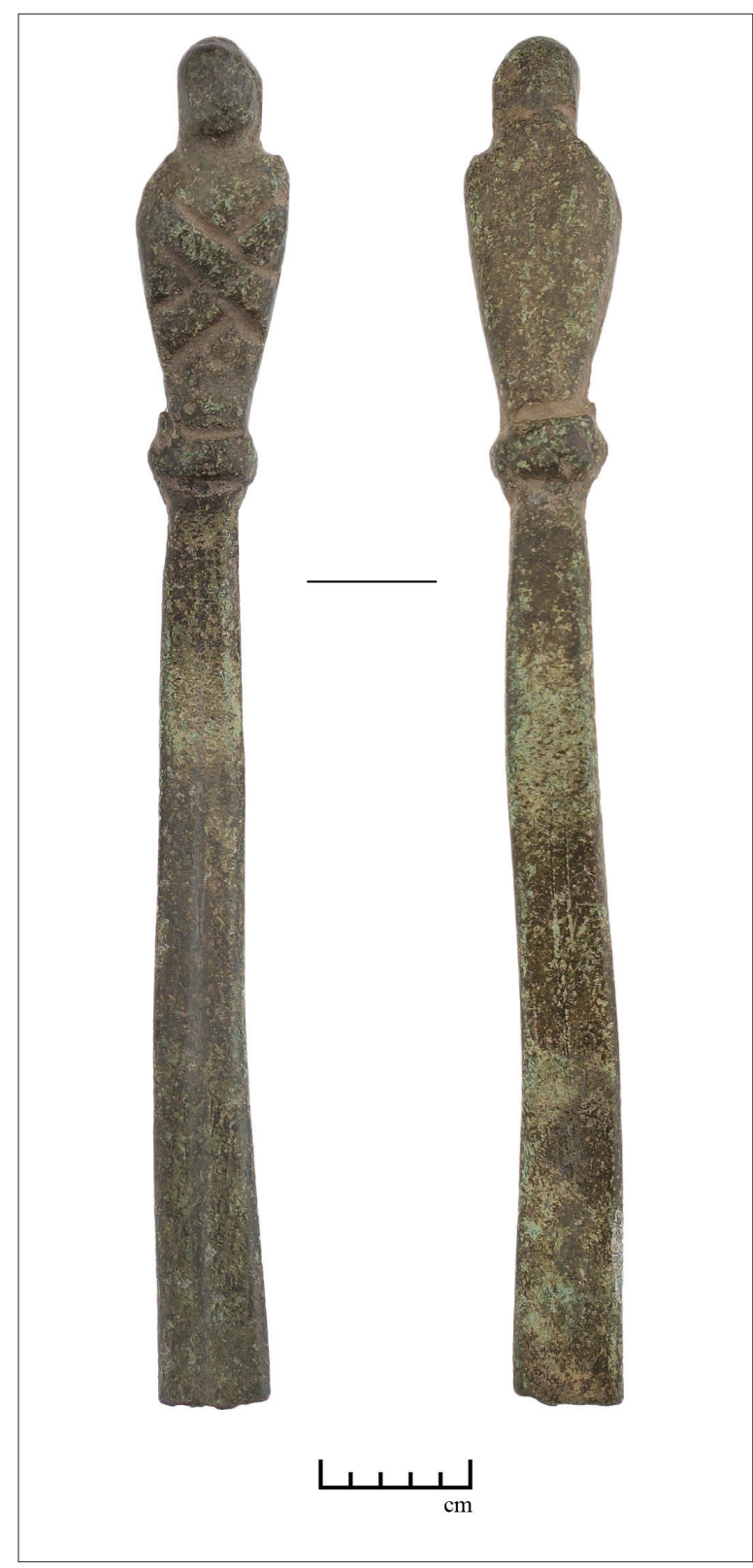

Fig. 12. The apostle spoon from the Akmenè or Mažeikiai region (AIM PŠ 45) (photograph by Skaiste ArdavičiūtèRamanauskienè).

Kaunas. An apostle spoon was found in Kaunas in a completely different context from the previous ones. This fragment of brass apostle spoon (KMM inv. GEK 11085) was found during excavations at Kaunas' Bernardine friary in 2016, in a vestry together with other 17th to 19th-century finds (Balčiūnas 2016) (Fig. 11). The friary and the church of St George the Martyr were founded in the 16th century, and suffered several times in fires and wars (Balčiūnas 2016). The fragment of brass apostle spoon comprises a figure and a tapering hexagonal handle. The figure is standing on a double hexagonal base, is wearing a long robe, and is holding an open book in the left hand. The object in the right hand is round and should represent a money bag, an attribute of St Matthew. This apostle spoon could have
II

THE MATERIAL OF MEDIEVAL AND NEW AGES: SOCIAL INTERACTIONS BETWEEN COMMUNITIES 


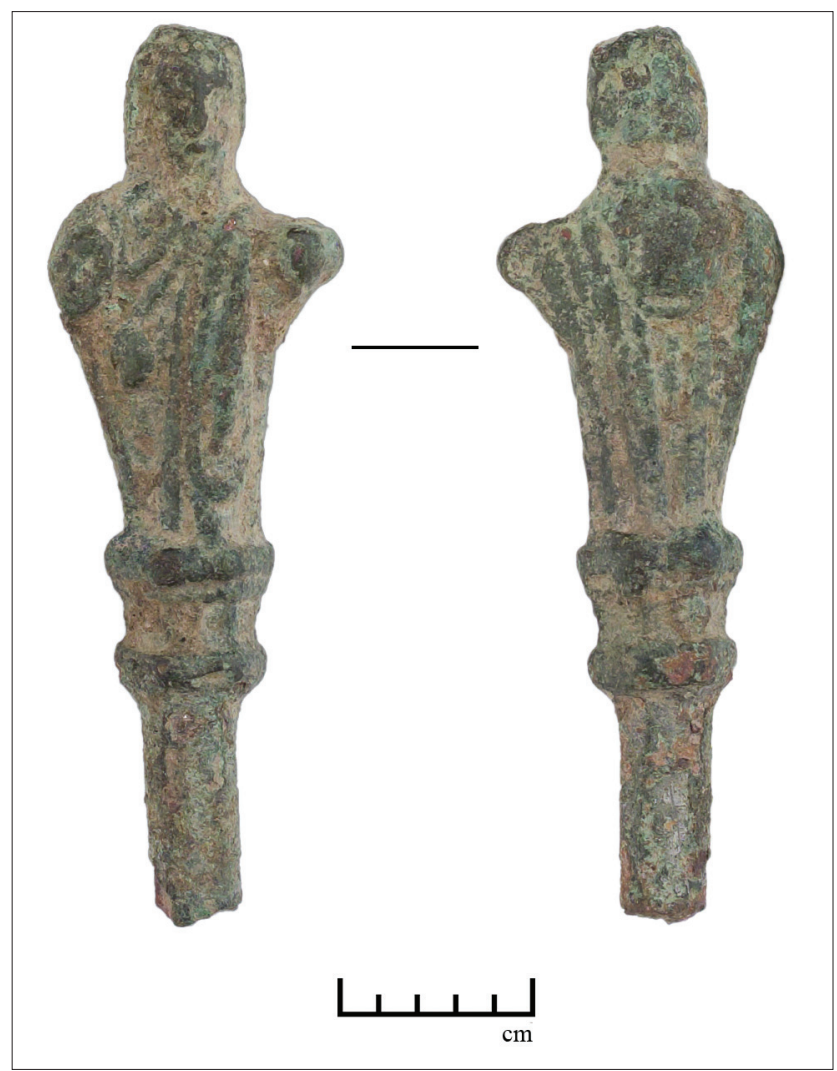

Fig. 13. The apostle spoon from the Kaunas district (AIM PŠ 112) (photograph by Skaistė Ardavičiūtė-Ramanauskienė).

been used in ceremonies in the church, or it could have belonged to one of the friars. Or it could have ended up there accidentally during numerous renovations and earth-moving work in the monastery after the many wars.

Unknown locations. The last two apostle spoons are from Akmenè History Museum. Unfortunately, there are no records of their exact find location and context. But at least it is known that they were found in Lithuania, and that AIM inv. PŠ 112 came from somewhere in the Kaunas district, and AIM inv. PŠ 45 came from either the Akmenė or Mažeikiai region (A. Ostrauskis, personal communication, 28 August 2018). It is possible that they were found in unknown manor sites that were destroyed during the wars between 1654 and 1667 and are now arable land. The first fragment (AIM inv. PŠ 45) comprises a figure and a tapering hexagonal handle with a groove (Fig. 12). The figure is standing on an oval base decorated with oblique grooves, and is holding an X-shaped attribute (saltire cross) of St Andrew. A similar apostle spoon with St Andrew was found in the Palace of the Grand Dukes in Vilnius. The other fragment of brass apostle spoon (AIM inv. PŠ 112) comprises the figure and a short length of hexagonal handle (Fig. 13). The figure is standing on a double hexagonal base, is wearing a long robe, and is holding a book in the left hand, while the right hand is empty. It has a hat on its back, enabling identifica- tion as St James the Greater. A similar apostle spoon depicting St James the Greater was found in Ii, Finland (Immonen 2005, f. 3).

\section{Discussion: identification of apostle spoons and their provenance}

Each apostle has a number of attributes by which he is recognised (Lanzi, Lanzi 2005). From the spoon maker's point of view, the apostles and their attributes had to be easily recognisable, and in order to achieve that they used contemporary art as their template (Rupert 1929). However, the same attributes can belong to several apostles, and their inconsistent representation by spoon makers can make them hard to discern, particularly in the case of individual apostle spoons (Immonen 2005). Another difficulty in identifying apostles comes from the way they were made. Separately cast objects for brass apostle figures in nearly all cases are lost, whether it happened before disposal or after. Sometimes the figures and their attributes are too badly cast, or they are too worn, to be recognisable.

Only five apostles from the 12 apostle spoons analysed could be identified: two as St James the Greater, two as St Andrew, and one as St Matthew. Two figures look as if they could be St Bartholomew, one might be St Matthew, and the last four cannot be identified. Although 
12 fragments of apostle spoons is not a large enough number of samples to draw precise conclusions, certain similarities in the characteristics and the patterns can be observed. The apostles St James the Greater and St Andrew dominate, followed by St Matthew and St Bartholomew according to the number of occurrences. A similar pattern can be identified with the six Finnish copper alloy apostle spoons, two of which were determined to be St James the Greater, two St Matthew, and one St Philip (Immonen 2005). These apostles were not so popular in Switzerland. It was the opposite: St Simon and St Peter were the most popular, and St Philip and St Bartholomew were the least popular (Marquardt 1997, 92). It is important to mention that this is only valid for silver apostle spoons.

The most popular saints and names in the Grand Duchy of Lithuania in the 16th and 17th centuries were St John (both the Baptist and the Evangelist), St Paul, St Peter, St James (the Greater and Lesser), St Andrew and St Bartholomew (Paknys 2005, 54-56; Jovaiša 2005). Popular names in Vilnius in the 17th century were St Bartholomew, St Matthias, St Matthew, and St Simon the Zealot (Frick 2013, 135). The popularity of St James, St Andrew, St Bartholomew and St Matthew is reflected in the apostle spoons identified, the most revered saints and popular names in the Grand Duchy of Lithuania. The most popular names became more diverse during the 17 th century, and while the popularity of certain names varied over time, the most recurrent name was John (Paknys 2005). These names match very well with the figures of the apostle spoons that were found, leading to the assumption that apostle spoon figures might correlate well with popular saints in their respective countries.

While many studies have been carried out on the cult of saints and popular names for children during the Late Medieval and Post-Medieval periods in Europe (Paknys 2005), the lack of investigations into apostle spoons in Europe does not allow us to draw certain conclusions on the supposed correlation between the popularity of saints, names and apostle spoons.

Larger numbers of brass apostle spoons started to appear in Western Europe in the second half of the 16th century; but their production peaked at the end of the 16 th century, and stopped at the end of the 17th century (Price 1908; Emery 1976; Homer 1999; Immonen 2005). Despite their considerable number all over Europe, the exact production centres of apostle spoons are still not known. In analysing Medieval and Post-Medieval spoons from Europe, J. Emery (1976) noticed that there were differences between apostle spoons made in England and in German-speaking regions (Germany, the Netherlands, Switzerland). The main difference lies in the shape of the figure. The figures from Germanspeaking regions are much better proportioned, and have more pronounced features than the English ones; whereas English figures are more like dolls, and follow closely the style of silver ones (Emery 1976, 124, 180; Homer 1999, 10). In addition, analogues of apostle spoons from German-speaking regions revealed that they varied greatly in size and style, while English ones retained consistent dimensions and forms of the figures (Marquardt 1997; Homer 1999; Amme 2007).

Many apostle spoons that could be stylistically assigned to England have a round bowl and a handle with a groove in the middle, a characteristic of 17th-century continental spoons. However, many of these spoons have a maker's mark of two or three miniature spoons in a circle punched into the bowl of the spoon. These marks are found on most brass spoons of various types in England (Price 1908). Sometimes the inscription 'DOVBLE WHITED' is near the miniature spoons, which indicates clearly that the spoons were made in England (Emery 1976; Homer 1999, 26). J. Emery (1976) suggested that despite the marks punched in the bowl, these spoons could have been made on the Continent for the English market (Emery 1976, 85). However, it is more likely that English spoon makers made spoons for the continental market, copying contemporary forms of bowls and grooved handles typical of Europe, but with apostle figures of their own design.

Judging by the stylistic features of the figures of the brass apostle spoons found in Lithuania and the numerous analogues from Europe, it can be concluded that they were imported to the Grand Duchy of Lithuania from centres of spoon production in England and German-speaking regions. Five apostle spoons (LDKVR inv. 31, LNM inv. AM 3:18, AM 57:6, KMM inv. GEK 11085, AIM inv. 112) which have doll-like figures were made in England. Two other apostle spoons (LDKVR inv. 1474 and LNM inv. AV 76:1), judging from their well-proportioned figures in different sizes and styles, were made in German-speaking regions. The other four brass apostle spoons have similar features both to those made in England and in German-speaking regions. Both LDKVR inv. 1470 and AIM inv. PŠ 112 have the same type of figure standing on an oval base decorated with oblique grooves. Judging from the form of the figures, which are neither like dolls nor statues, and from the oval base on which they are standing, these spoons could have been made either in German-speaking regions or in England. The same applies to the apostle spoons from the Palace of the Grand Dukes (LDKVR inv. 2221) and Jakštonys manor (LNM inv. AM 71:1) in Lithuania. The apostle spoon from Šventaragis Street (LNM inv. 76:1) is typologically and stylistically different to all the other ones. According to J. Em-

\section{II}

THE MATERIAL OF MEDIEVAL AND NEW AGES: SOCIAL INTERACTIONS BETWEEN COMMUNITIES 
ery, this type of spoon, although made from silver, was made in Poland and German-speaking regions (Emery 1976, 109). Many examples are known from Germany, Poland and also Latvia (Marekowska 1954, 136; Marquardt 1997, 46-47; Avižinis 2017, f. I.1). An almost identical depiction of the Šventaragis Street apostle is found on one of the 12 apostle spoons with the Szeliga and Przeginia coats of arms in the National Museum in Kraków, Poland (Kilijańska 2018). Therefore, it is possible that the apostle spoon from Šventaragis Street could have been made in Poland and brought to be sold in Vilnius. Alternatively, an artisan who came from Poland could have made the spoon.

\section{Conclusions}

For a long time it was thought that apostle spoons were made as christening gifts. However, as this research shows, there is no evidence to prove this belief with certainty. Inscriptions of the dates and names of baptised children were also made on other kinds of silver spoons. As various inventories show, apostle spoons were also used as diplomatic gifts, and for representational purposes by their owners.

Ten apostle spoons, or, to be more precise, fragments of apostle spoons, were found in Lithuania in archaeological excavations and site surveys, and two were brought to the museum by people who found them on their land. The distribution map reveals that all the apostle spoons were found inland, with the largest number concentrated in Vilnius, the capital of the Grand Duchy of Lithuania. A completely different pattern emerged in Finland, where six apostle spoons were found in coastal areas of the country (Immonen 2005, 193).

Qualitative and quantitative analyses of the material of nine apostle spoons found in Lithuania revealed that eight were cast from copper and zinc alloy with minor traces of lead, tin and iron, and one was cast from lead and tin alloy. Three of the spoons were tin-plated.

The apostle spoons that were found in Lithuania were most likely made in the 17th century, and, as their contexts suggest, used until the first half of the 18th century. These dates correlate with the production and use of apostle spoons in other countries in PostMedieval Europe. Judging by the limited number of finds, the level of popularity of apostle spoons in the Grand Duchy of Lithuania was lower than in countries in Western Europe.

Only five apostles from the 12 apostle spoons analysed could be identified with certainty: two as St James the Greater, two as St Andrew, and one as St Matthew.
They correlate well with the most popular saints and names in the Grand Duchy of Lithuania in the 16th and 17th centuries, and although 12 fragments of apostle spoons is not a large enough number to draw precise conclusions, certain similarities in characteristics and patterns can nonetheless be observed.

The features of the apostle spoon figures indicate that they were imported to the Grand Duchy of Lithuania from England and continental Europe. Judging from the stylistic features of the figures and analogues, most of the apostle spoons (five in total) were made in England. Two other spoons came from continental Europe (Germany, the Netherlands, or Switzerland), while the other four might have come from either. Only one apostle spoon, which is typologically and stylistically different to the others, might have been made in Poland, or it might have been made locally by an artisan who came from Poland.

Undoubtedly, there may be more apostle spoons or fragments of them that have not yet come to the author's attention. Unwritten archaeological reports, misidentified apostle spoons, and widely dispersed museums limited the scope of the research.

\section{Acknowledgements}

I would like to extend my heartfelt thanks to L. Grabauskaite, of the Pranas Gudynas Restoration Centre, for her kind help in doing XRF analysis of the spoons, and her expert advice. Also, a big thank you to R. Prielgauskiene, from the Restoration Centre of the National Museum of Lithuania, for her micro-chemical analysis of the spoons, and to M. Steponavičiūte, of the Research Centre of the National Museum-Palace of the Grand Dukes of Lithuania, for the SEM-EDX analysis of the spoons. I would also like to thank A. Ostrauskis, head of Akmene History Museum, for his kind assistance with unknown apostle spoons.

\section{Abbreviations}

AIM - Akmenè History Museum

KMM - Kaunas City Museum

LII - Lithuanian Institute of History

LNM - National Museum of Lithuania

LDKVR - National Museum-Palace of the Grand Dukes of Lithuania

VINLAS - Department of Medieval and Post-Medieval Archaeology, National Museum of Lithuania 
References

\section{Manuscripts}

BALČIŪNAS, D., 2017. Kauno senamiesčio (20171) teritorijos Kauno m. sav., Kaunas, Papilio g. 9 (u/k 22350) $2016 \mathrm{~m}$. detaliuju archeologinių tyrimų ataskaita. In: LII, file B. 7764

IVANAUSKAS, E., 2001. Lazdijų rajono neaiškių archeologijos objektų $2001 \mathrm{~m}$. žvalgymai ir žvalgomieji tyrimai. In: VINLAS, file 282

IVANAUSKAS, E., 2003. Archeologinių žvalgymų metu Jonavos, Jurbarko, Kaišiadorių, Kauno, Kèdainių, Molètų, Raseinių, Rokiškio, Šakių, Trakų, Varènos rajonuose 19862002 m. ir atsitiktinai Kauno mieste, Nemuno pakranteje, 1977-1985 m. rastų radinių sąrašai. In: VINLAS, file 336 A

OSTRAUSKIENĖ, D., 2018. Vilniaus senojo miesto vietos su priemiesčiais (25504), Vilniaus senamiesčio (16073), Vilniaus m. sav., Vilniaus m., Pylimo g. 56 2017-2018 m. žvalgomųjų archeologinių tyrimų ir archeologinių Žvalgymų ataskaita. In: VINLAS, file 1145

OŽALAS, E., 2003. Vilniaus Žemutinès pilies Valdovų rūmų teritorija. Pietinio, rytinio ir vakarinio korpusų prieigų 2002 m. archeologinių tyrimų ataskaita. In: LII, corpus 1, file B. 4251

RACKEVIČIUS, G., 2003. Vilniaus Žemutinès pilies Valdovų rūmų teritorija. Šiaurinio korpuso prieigų archeologinių tyrimų 2002 m. ataskaita. In: LDKVR, corpus 1 , file 1

VEŽEVIČIENĖ, V., 2014. Vilniaus senamiesčio (16073), Vilniaus senojo miesto vietos su priemiesčiais (25504), Šventaragio g. archeologijos detaliųjų tyrinėjimų $2013 \mathrm{~m}$. ataskaita. In: VINLAS, file 1013 A-G

\section{Literature}

AMME, J., 2007. Historische Bestecke II. Supplement zu AMME 2002. Stuttgart

AVIŽINIS, D., 2017. Senasis Baltijos sidabras iš privačios kolekcijos. Baltic silver antiques from a private collection. Das alte Baltische Silber aus einer Privatsammlung. Vilnius

CARVER WEES, B., 1997. English, Irish and Scottish Silver at the Sterling and Francine Clark Art Institute. New York

COLMAN, G., 1811. The Dramatic Works of Beaumont and Fletcher: printed from the text and with the notes of the late George Colman. Vol. III. London

DAMBRAUSKAITĖ, N., 2017. Bajoru namu ūkis Lietuvos Didžiojoje Kunigaikštysteje XVI a. - XVII a. pirmojoje pusejje (PhD thesis). Vilnius University

DOLCZEWSKI, Z., 2006. Poznanskie nakrycia i zastawy od XVI do XVIII wieku. Torun

DUNGWORTH, D., 2005. Metallurgical analyses. In: G. EGAN (ed.). Material culture in London in an age of transition. Tudor and Stuart period finds c 1450-1700 from excavations at riverside sites in Southwark. London, 227241

EMERY, J., 1976. European spoons before 1700. Edinburgh FRICK, D., 2008. Wilnianie. Żywoty siedemnastowieczne. Warszawa

FRICK, D., 2013. Kin, kith and neighbours. Communities and confessions in seventeenth century Wilno. New York

GRAUDONIS, J., 2003. Turaidas pils II. Atradumi. Riga
HARRIS, W., 1950. The education of a spoon collector. The Connoisseur, 134, 28-34

HOMER, R. F., 1999. Five centuries of old base metal spoons. London

HOWARD, M., 1903. Old London Silver: is history, its makers and its marks. New York

IMMONEN, V., 2005. Six apostle spoons from Finland. Post-Medieval Archaeology, 39, 186-196

JACKSON, C. J., 1892. The Spoon and its history: its form, material, and development, more particularly in England. Archaeologia, 53:1, 107-146

JOVAIŠA, L., 2005. Krikšto vardai XVII a. pirmos pusès Lietuvoje. In: M. PAKNYS (ed.). Šventieji vyrai, šventosios moterys. Šventujų gerbimas $L D K X V$-XVII $a$. Vilnius, 147-184

KILIJAŃSKA, A., 2018. Set of twelve spoons with busts of the Apostles and the Szeliga and Przeginia coats of arms. [online] Available from: http://muzea.malopolska.pl/en/ obiekty/-/a/26885/1117716 [accessed 1 August 2018]

KRIEGSEISEN, J., 2014. Das Silber des Danziger Stadtrates. Zwischen Finanzmöglichkeiten und Prestige einer Stadt. Gemeine Artefakte 2. [online] Available from: http://www. kunsttexte.de/ ostblick [accessed 1 August 2018]

LANZI F., LANZI G., 2005. Šventieji globejai ir ju simboliai. Vilnius

MAREKOWSKA, B., 1954. Kolekcja srebrnych łyżek polskich z w. XVI i XVII. (Przyczynek do dziejów polskiej kultury materialnej i artystycznej). Rozprawy i Sprawozdania Muzeum Narodowego w Krakowie, 125-148

MARQUARDT, K., 1997. Eight centuries of European Knives, Forks and Spoons: an Art Collection. Stuttgart

MIŠKINIS, A., 1999. Užnemunès miestai ir miesteliai. Vilnius

PAKNYS, M., 2005. Šventuju kultai LDK XV-XVII a. pradžioje. In M. PAKNYS (ed.). Šventieji vyrai, šventosios moterys. Šventujų gerbimas $L D K X V$-XVII a. p. Vilnius, 15-92

PRICE, F. G. H., 1908. Old base metal spoons. London

RUPERT, C. G., 1929. Apostle Spoons. Their Evolution from Earlier Types and the Emblems Used by the Silversmiths for the Apostles. London

SUNDMARK FALLBERG, S., 2017. Dining with Christ and His Saints. Tableware in Relation to Late Medieval Devotional Culture in Sweden. Konsthistorisk tidskrift/ Journal of Art History, 86:3, 219-235. [online] Available from: http://dx.doi.org/10.1080/00233609.2017.1352619 [accessed 1 August 2018]

WESTMAN, H. O., 1844. Transactions of the Society of Literary \& Scientific Chiffoniers; being essays on primitive arts in domestic life. The Spoon, with upwards of one hundred illustrations (primitive, Egyptian, Roman, Mediaeval and Modern). New York

WILSON, T., 1984. Spoons with a taste of history. British Museum Society Bulletin 46, 24-27.

Skaiste Ardavičiūtè-Ramanauskienè Senior museologist and PhD student (Department of Archaeology, Vilnius University) Department of Medieval and Post-Medieval Archaeology National Museum of Lithuania

T. Kosciuškos St 3, LT-01100, Lithuania,

+37067812698

E-mail: skaiste.ardaviciute@gmail.com

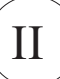

THE MATERIAL OF MEDIEVAL AND NEW AGES: SOCIAL INTERACTIONS BETWEEN COMMUNITIES 


\section{ŠAUKŠTAI SU APAS̆TALŲ \\ FIGÜROMIS LIETUVOJE}

\section{SKAISTE் ARDAVIČIŪTÉ- RAMANAUSKIENE்}

\section{Santrauka}

Vèlyvaisiais viduramžiais ir naujaisiais laikais šaukštai Vakarų Europoje buvo gaminami su ịvairiomis figūromis rankenų galuose. Vienas iš šių tokių šaukštų tipų randamas ir Lietuvos archeologineje medžiagoje - tai šaukštai su apaštalų figūromis. Ilgą laiką buvo manoma, kad šaukštai su apaštalų figūromis buvo gaminti tik kaip dovanos krikštynų proga. Tačiau kaip atskleidè ivvairiu inventorių analizè, šie šaukštai buvo naudojami ir reprezentacijai bei kaip diplomatinès dovanos.

Archeologinių kasinejjimų ir žvalgymų Lietuvoje metu buvo rasta dešimt šaukštų su apaštalais fragmentų. Dar du pateko ị muziejų iš neaiškių radimo vietų. Didžiausias šių šaukštų kiekis buvo rastas Lietuvos Didžiosios kunigaikštystės sostinèje Vilniuje. Devynių šaukštų su apaštalais metalo lydinių kokybinè ir kiekybiné analizé atskleidè, kad aštuoni buvo pagaminti iš vario ir cinko lydinio su nedidelèmis švino, alavo ir geležies priemaišomis, o vienas - iš švino ir alavo lydinio. Keturi iš jų buvo alavuoti.

Atliktas tyrimas parodé, kad šaukštai su apaštalų figūromis greičiausiai pagaminti XVII a. ir, kaip rodo jų kontekstas, buvo naudojami iki XVIII a. pirmosios puses. Šios datos koreliuoja su šių šaukštų gamyba ir naudojimu kitose Vakarų Europos šalyse. Sprendžiant iš gana mažo šių radinių skaičiaus, lyginant su kitomis Vakarų Europos šalimis, šaukštai su apaštalu figūromis Lietuvos Didžiojoje Kunigaikštystėje galèjo būti ne tokie populiarūs kaip kitose Vakarų Europos šalyse. Iš dvylikos analizuotų šaukštų su apaštalų figūromis tik apaštalai ant penkių šaukštų buvo identifikuoti. Du iš jų identifikuoti kaip Šv. Jokūbas Vyresnysis, du - kaip Šv. Andriejus ir vienas - kaip Šv. Matas. Nors šis skaičius per mažas konkrečioms išvadoms daryti, bet palyginus XVI-XVII a. Lietuvos Didžiojoje Kunigaikštystejje populiarius šventuosius ir jų vardus su gautais tyrimo rezultatais, jie sutampa.

Šaukštų su apaštalais stilistinè analizè atskleidè, kad jie buvo pagaminti ir ị Lietuvos Didžiają Kunigaikštystę importuoti iš Anglijos ir vokiškai kalbančių šaliu (Vokietijos, Nyderlandų arba Šveicarijos). Remiantis šaukštų su apaštalais figūrų stilistika ir analogijomis, penki šaukštai buvo pagaminti Anglijoje, du - vienoje iš vokiškai kalbančių šalių. Kiti keturi šaukštai su apaštalais galèjo atkeliauti iš bet kurios iš šių šalių, nes jų stilistiniai bruožai apima tiek Anglijoje, tiek kitose Vakarų Europos šalyse gamintų šaukštų su apaštalais būdingus bruožus. Šaukštas su apaštalu iš Šventaragio gatvès, kuris tipologiškai ir stilistiškai skiriasi nuo visų kitu prieš tai apibūdintujų ir kurio analogų daugiausia galima rasti Lenkijoje, greičiausiai ir buvo pagamintas Lenkijoje arba ši šaukštą galèjo pagaminti amatininkas, atvykęs iš Lenkijos ị Vilnių. 